\title{
To the American food justice movements: A critique that is also an offering
}

COMMENTARY ON RACE AND ETHNICITY IN FOOD SYSTEMS

\author{
Marcelo Felipe Garzo Montalvo* \\ Oakland, California
}

Submitted June 16, 2015 / Published online August 30, 2015

Citation: Garzo Montalvo, M. F. (2015). To the American food justice movements:

A critique that is also an offering. Journal of Agriculture, Food Systems, and Community

Development, 5(4), 125-129. http://dx.doi.org/10.5304/jafscd.2015.054.017

Copyright (C) 2015 by New Leaf Associates, Inc.

\author{
Abstract \\ a love letter, \\ that is also a Dear John letter \\ an invitation, \\ that is also a plea \\ a vision, \\ that is also a grievance \\ that is also a call to action
}

\section{Keywords}

cultural work, critique, food justice, movement strategy, movement building, organizational development, personal reflection, la cultura cura, visionary activism, transformative justice

$\mathrm{T}$

o the American Food Justice Movements:

Thank you for your work. Thank you for the time, energy, and love you are all offering to

* Marcelo Felipe Garzo Montalvo, Oakland, California USA; marcelo.garzo@gmail.com protect our dear Mother Earth. Thank you for defending our seeds, for growing dark and healthy soil, for fighting to defend our waters, for working in the interest of Life and all our relations. Thank you for caring about the young people in our communities, providing meaningful jobs, ways to find training and work (paid or not) that support the health and wellness of our communities. Thank you for honoring our elders, for respecting our ancestors' wisdom and ways of knowing across generations. Thank you for farmers' markets, community gardens, healthier corner stores, educational kitchens, grassroots restaurants, and food trucks. Thank you for seed banks and seed bombs, time banks and radical skill shares. For worker-owned cooperatives, land trusts, and community supported food systems. Thank you for the songs, poems, performances, books, novels, and documentary films. Thank you for permaculture, agroecology, and for supporting the struggles of food and farm workers. Thank you for cultivating, nurturing, planting, watering, waiting, protecting, 
pruning, thinning, harvesting, cooking, eating, composting, and turning under. Thank you for tending to these cycles of life and death that make our existence possible. Thank you for your thoughts, your energy, for walking these prayers.

Thank you for caring about the suffering of others. Thank you for taking care of yourself. Thank you for wanting to do something to respond to the injustices you see in our food system.

My gratitude for you all is overflowing, not just for how much I have personally benefited from being a part of this movement, but also for how much "impact" I have already seen us have. Our movements have already begun to transform our food systems. I give thanks for how this work has supported my own family, my relatives, my communities, the children, my peers, students, coworkers, etc.

Rooted in this love and gratitude, I want to offer a space to "check-in"- - an invitation to slow down and consider some ways that I have also felt upset by this movement. Nobody is forcing you to read this, but I am asking, for a bit of time and space and energy, for my feelings to be heard and considered as a part of y/our community, y/our struggle.

Why should you care?

Because I am no better, nor worse, than any of you, than any of us.

And who am I to offer these comments?

I am a "person of color" who has been directly involved in "food systems work" since 2007. I am someone who felt moved to respond to this call for commentaries... and I fit the description. Also, I am your brother, your relative.

Speaking, and thinking from my own personal realities, my lived experiences and shifting identities, I offer these thoughts, for us to consider, in a conversation on "race and ethnicity in food systems work."

When I received this call for commentaries through various listservs (food_justice [GFJ],
CRT_FOOD, URBANAG, etc.), I immediately opened a word .doc and began writing. At first all that came out were my grievances, which I will also share here, but after careful reflection, I could not offer my grievances without rooting them in my hopes, my visions, as well as my gratitude. I honor Grace Lee Boggs here for this reminder, for her teachings and guidance on how this work takes time, effort, and the energy to honor and witness our reactionary energy, as it slowly transforms into visionary and (r)evolutionary critique (Boggs, 2011).

As I kept writing, my grievances were many, but as I sat and observed them over time my visions and hopes showed through, and became more abundant—not only more numerous, but also more powerful. In sitting with and writing down my woundings, I opened to vulnerability, making possible the spirit of connection, as I pray for the possibility of healing.

The heart of my grievances, and also my visions, is our collective mis/understandings of "power, privilege, and oppression," and therefore how we strategize their undoing and/or transformation through food systems work. I have often felt frustrated and stuck when it comes to how we understand and define the "political," and what that means for food justice movements. I have felt limited, even blocked, by bourgeois understandings of "politics," asking me to operate within the narrow and limited confines of "policy work" and other top-down strategies for change: organizing campaigns, appeals to elected officials, ballot measures, and/or nonprofit bureaucracy. There is often an unspoken, or sometimes explicitly stated, preference for this type of work, a privileging of the most concrete and tangible "victories" for us to celebrate. Organizational and community capacities are focused on strategizing, measuring, and evaluating our "impact" through this discourse, this lens.

Power, privilege, and oppression are "structural," in the sociological/anthropological sense of the term, and also in the ways that countless antioppression and antiracist trainings make clear. However, what can be lost or overshadowed in a perspective, and "training," that is solely focused on structural change and "policy work" (or on 
nonprofit organizations driving and defining community change) is the opportunity to transform our everyday shared practices that re-perform and reproduce these structures of power. It is this space of the everyday that I would like to refer to as "culture," and its accompanying activism: "cultural work." To be sure, here my critique is not of "policy work" itself, because it is obviously and urgently important work to be done. Instead, what I am asking for is a shift, an expansion, an integration of our understandings of power itself, and therefore a turn in some of our activist energy as we also consider another point of focus - that is, the cultural. This is not to suggest that food justice workers are not already doing any cultural work; in fact, much of my own understandings of cultural work that I am sharing here have been developed through my own experiences within many food justice organizations. But what I'd like to reflect on, and bring into question, are my repeated experiences over time and place of fellow food justice organizers and workers marginalizing, postponing, silencing, ignoring, or not knowing how to practice and engage cultural work.

Cultural work does not refer only to the practice of art-making — poetry, music, film, photography, murals, etc.- - though this work is necessary to any sustainable social movement. Instead, my theorizing of cultural work asks us to focus on our everyday shared practices, on our collective actions, our common doings, or in Spanish, our vida cotidiana. In this way the everyday is a space, a location from which we can "strategize, measure, and evaluate" our work. By everyday shared practice I refer to the things we do, every day. This means language, clothing, shelter, transportation, ethics, mathematics, and where and how we consume food and water (of course, we're food activists!), just to name a few examples. In verbs it means: eating, sleeping, going to the bathroom, walking, driving, sitting, breathing, talking, listening, cooking, sharing, caring, calling, working, thinking, storytelling, planning, designing, reading, writing, drawing, singing, etc. These are sites of culture, and thus cultural work refers to the forms of activism that seek to transform these spaces that are numerous, vast, and yet intimate. Cultural work is, in short, a lot of work!
Before this understanding of cultural work becomes too abstract, let us situate it within the context of this conversation on the culture of food justice movements, and our related organizational practices. Already I need to point out how much of our movement culture is based on being affiliated with an organization (nonprofit, nongovernmental organization [NGO], for-profit, limited liability corporation [LLC], etc.), and how this itself is a cultural move. Normalizing this approach-that is, professionalizing activism —ends up making this work inaccessible to many people in our communities. (I prefer to discuss access rather than exclusion/inclusion.) Building a movement that is based on having the privileges that are necessary to access nonprofit organizations and/or NGOs is precarious and not sustainable in that it creates a culture in our movement that doesn't recognize that social movements must be, first and foremost, social. In other movements and parts of the world (outside the United States in particular) activists including those in the food movement understand themselves in relation to NGOs, but not as being NGOs themselves. In fact, many social movements that are rooted in the Global South (Via Campesina in particular) are deeply critical of how NGOs become proxies for multinational corporations and other imperial projects. This then becomes a site of cultural work. How are we going to do the "work" of undoing the nonprofit industrial complex and its influence on our social movement (INCITE! Women of Color Against Violence, 2007)? It is the role of cultural work itself that would allow us to have this conversation and take the time and energy needed to look at how middle-class, bourgeois, corporate culture is being re-articulated and re-inscribed in many of our food justice projects precisely because we are looking elsewhere for the "work to be done."

It is in the context of these movement spaces that I have been asked, or called in as a "consultant," to discuss "anti-oppression," "anti-racism," or other ways to engage the perennial (and very frustrating) question of "why are there no people of color here?" Or more often than not, "why is there a lack of diversity in our organization?" or "how can we be more inclusive?" It must be noted that "lack of diversity" and "inclusive" are often 
neoliberal code words for a space being already white-dominated. When I see a call for papers asking for a list of "how tos" for working with people and communities of color in food systems, I am reminded of the dozens of times I have been asked these sorts of questions, and the dozens of times I have been unable to offer the prescriptive answers these folks may be seeking. Many times when I hear these code words, I fear it is already too late. A space and culture has already been created and established that is so thoroughly white (corporate [we don't need to be a corporation to be corporate] and heteropatriarchal [dominated by the norms of heterosexual males]), that it contains within it one of the hallmarks of whiteness itself: white guilt and its accompanying savior complex.

Looking through the lens of culture, the American food justice movement often resembles a performance of middle-class, corporate cultural norms themselves. Part of this culture has also been a confusing overemphasis on race and antiracism and an almost complete erasure of other systems of domination that make white supremacy even more durable, not the least of which are analyses of class (neoliberal capitalism) and gender (heteropatriarchy), and how deeply these systems affect our cultural practices as movement organizers. I share this as a middle-class, raised uppermiddle class man of color who is the son of two physicians. In other words, I have felt comfortable participating (or even have been able to participate) in the food justice movement precisely because of my class and educational privilege, and I am taken more seriously with fewer qualifications because of male privilege and (at times) straight-passing privilege. How are we ever going to dismantle food injustice, whose very roots are situated in neoliberal capitalism and heteropatriarchy (in other words, the dominant culture) if we are re-performing these systems in our everyday shared practices? Many of my visions for our movement include strategies that challenge the cultural practices that have been borrowed from the academic, nonprofit, and other industrial complexes that disrupt our ability to collectively transform ourselves and the food system, and that instead re-embed us in the status quo.
This critical cultural work can and will make us uncomfortable. It forces us to "grow our souls" (Boggs, 2011, p. 28), to engage in "spiritual activism” (Anzaldúa \& Keating, 2009, pp. 292, 323). This all sounds grandiose, but it is actually very humbling and unglamorous work to do. When I am asked how to engage in dismantling racism with an organization, I often suggest organizing an allstaff and community meeting where we project everyone's salary on the wall and see what happens. No place that I have worked has taken me up on this idea (yet!). Doing this will make them uncomfortable. It will make me uncomfortable. But not knowing each other's salary, and it being taboo to even ask or share this information, is part and parcel of neoliberal capitalist culture. Normalizing these sorts of silences is precisely how they are perpetuated and made invisible.

When we commit ourselves to moving together and collectively through the discomfort of breaking these silences and seeing where it takes us, that is cultural work. This is the inner, personal, and interpersonal growth and working through fear (and other feelings we don't like) that is necessary to shifting culture. Building relationships and trust is not only a part of cultural work, it is cultural work itself.

In Spanish there is a cross-cultural dicho (saying), la cultura cura, that translates to English as "culture cures" or "culture is healing." Here la cultura is referring explicitly to our indigenouscentered and ancestrally oriented ways of knowing that have helped us survive, and continue to thrive, in a dominant culture that is based on our erasure, a culture that normalizes violence and genocide, a culture that silences its survivors (MarTínez, 2013). Survival is an everyday shared practice in many communities of color. In this way, cultural work, like healing work, emphasizes process rather than an end product, making it much more difficult to measure and apply for grants to fund. But imagine how deeply we could transform our food systems if we committed to ending a culture of genocide, slavery, sexual violence, and the like. What would our work look like if we shifted from asking how to "attract diversity" to our organizations, and instead asked how to dismantle the cultures that oppress communities of color on a daily basis? 
Everyone can and needs to participate in this level of cultural work, of transformation, if we wish to overcome age-old tropes like tokenizing (turning people of color into a gimmick to sell our work) or other forms of retraumatizing and rewounding.

With this I will end as I began, with a prayer of gratitude. To all my relations, for everyone who is present in this piece and in our work, whether I know your name or not, I honor you. My visions, my grievances, I present to you as an offering, an invitation, to be in movement together, to honor our "precious knowledge," shedding the autumn leaves of a dying neoliberalism, to feed the roots of our Mother Earth, the land, that is our home in the cosmos, that is our source.

\section{References}

Anzaldúa, G. (Author), \& Keating, A. (Ed.). (2009). The Gloria Anzaldua reader. Durham, North Carolina: Duke University Press.

Boggs, G. L. (2011). The next American revolution: Sustainable activism for the twenty-first century. Berkeley: University of California Press.

INCITE! Women of Color Against Violence. (2007). The revolution will not be funded: Beyond the non-profit industrial complex. Cambridge, Massachusetts: South End Press,

Mar'Tínez, S. (2013). AmeriCaCa: Don't step in it! Don't bring it in the house!: The sounds of silenced survivors: Breaking the silence. Bloomington, Indiana: AuthorHouse. 